Research Article

\title{
Attitude on HIV/ AIDS and the Effectiveness of Structured Teaching Programme on Attitude regarding HIV/ AIDS among the Industrial Workers in a selected Public Sector Undertaking Agency at Cuddalore District, Tamilnadu
}

\author{
B Sivagamy', Karaline Karunagari'
}

${ }^{1}$ Lecturer in Nursing, ${ }^{2}$ Professor \& HOD, Rani Meyyammai College of Nursing, Thiruvetkulam, Annamalai Nagar, Chidambaram, Tamil Nadu, India.

DOI: https://doi.org/10.24321/0019.5138.202121

\section{I $\quad \mathbf{N} \quad \mathbf{F} \quad \mathbf{O}$}

Corresponding Author:

B Sivagamy, Rani Meyyammai College of Nursing, Thiruvetkulam, Annamalai Nagar, Chidambaram, Tamil Nadu, India.

E-mail Id:

sivagamy180270@gmail.com

Orcid Id:

https://orcid.org/0000-0002-7082-705X

How to cite this article:

Sivagamy B, Karunagari K. Attitude on HIV/ AIDS and the Effectiveness of Structured Teaching Programme on Attitude regarding HIV/ AIDS among the Industrial Workers in a selected Public Sector Undertaking Agency at Cuddalore District, Tamilnadu. J Commun Dis. 2021; 53(2): 18-27.

Date of Submission: 2020-12-23

Date of Acceptance: 2021-05-03

\section{$\begin{array}{llllllllllll}\mathbf{A} & \mathbf{B} & \mathbf{S} & \mathbf{T} & \mathbf{R} & \mathbf{A} & \mathbf{C} & \mathbf{T}\end{array}$}

Introduction: HIV, the virus that causes AIDS (Acquired Immunodeficiency Syndrome) has become one of the world's most serious health and development challenges. HIV not only affects the health of individuals, but also leaves severe impacts on households, communities, and the development and economic growth of nations. The worst affected is the business world, which is not only suffering from the cost of the workforce, but also the decrease in profits and productivity level both for the employers and the employees.

Methods: A quantitative research approach with pre-experimental one group pre-test-post-test design was used to identify the attitude towards HIV/ AIDS and to evaluate the effectiveness of the STP among 123 industrial workers using convenient sampling technique. Results:There was a favourable attitude towards the basic concept of HIV/ AIDS, treatment aspects, regarding HIV testing and in the prevention of HIV there was a minimal change in attitude; regarding the rights of the HIV affected people, there was a highly favourable attitude among the subjects and caring for the HIV positive people which indicated that the STP was effective.

Keywords: HIV, AIDS, Attitude, Testing, Prevention, Rights of HIV Patient

\section{Introduction}

The HIV/ AIDS epidemic has become a global crisis affecting the society at all levels. The worst affected is the business world, which is not only suffering from the cost of the workforce but also the decrease in profits and productivity level both for the employers and the employees.

One of the missions of the International Organization of Employers (IOE) is to facilitate the transfer of information. 
Shailesh K Kawale, et al. conducted a cross-sectional study to identify the attitude and preventive practices regarding HIV infection and AIDS among the postgraduate students of the University of Pune. ${ }^{1}$ There were misconceptions that mosquito bite would spread HIV and sharing food would transmit HIV.

Bowen, et al. conducted a study to explore the HIV/ AIDS intervention management practices of 12 construction firms/ industries in Cape Town of South Africa. ${ }^{2}$ They identified that the interventions should extend beyond awareness and prevention campaign treatment programmes.

Even today, despite the advances in our scientific understanding of HIV, its prevention, treatment, and significant effort taken by the global health community and leading government and civil society organisations, many people stand at risk for HIV; they don't have access to prevention, care and treatment. False beliefs and stigmatisation can lead to a situation in which the employee may be mistreated and discriminated against while making personnel decisions.

\section{Statement of the Problem}

Assess the attitude on HIV and evaluate the effectiveness of Structured-Teaching Programme on the attitude regarding HIV/ AIDS among the industrial workers in a selected Public sector undertaking agency at Cuddalore District, Tamilnadu.

\section{Objectives}

- To assess the existing level of attitude regarding Human Immunodeficiency Virus/ Acquired Immunodeficiency Syndrome among the subjects working in an industrial area.

- To evaluate the effectiveness of Structured Teaching Programme (STP) regarding the attitude on HIV/ AIDS among the subjects.

In the present study, the CIPP model, or Content, Input, Process, Product approach, developed by Stufflebeam (1983) was used.

\section{Review of Literature}

Maheswari and Muthamilselvi conducted a study to assess the effectiveness of the structured teaching programme on universal precaution among the class IV employees working at Aarupadai Veedu Medical College and Hospital, Puducherry. ${ }^{3}$ The results indicated that there was a significant increase in knowledge level in the post-test, 93\%, as compared to the pre-test. The researchers concluded that continuous reinforcement would enhance the knowledge among the class IV employees.

Mathew, et al. conducted a study to determine the effectiveness of STP on prevention and control of HIV/ AIDS among 100 pre-university college students using stratified random technique. ${ }^{4}$ The results indicated that there was a significant increase in the post-test knowledge (19.62) after the structured teaching at 0.05 significance level. The authors recommended that educating the adolescents regarding HIV/ AIDS was necessary to prevent its occurrence in the society.

Ouzouni $\mathrm{C}$ and Nakakis K conducted a study with four selfadministered instruments such as the International AIDS Questionnaire - Chinese version (IAQ-C), the source of HIV/ AIDS information questionnaire, sexual behaviour/ practices and attitudinal questions among the students. ${ }^{5}$ The student nurses had fairly good knowledge about HIV/ AIDS with a positive attitude towards AIDS people. They believed that mosquitoes transmit HIV, and that virus could be transmitted via the toilet.

Belay Tessema, et al. conducted a study to identify the behavioural aspects of readiness to adherence among 504 subjects receiving antiretroviral treatment. ${ }^{6}$ The unwillingness to the disclosure of HIV status was significantly associated with no readiness to highly active antiretroviral therapy (HAART). They concluded that the efforts should be taken for regular follow up to minimise non-adherence and no-readiness to HAART.

\section{Methods}

The research approach was quantitative in nature and the pre-experimental one group pre-test and post-test design was used. The study was conducted in Neyveli which is about 200 km from Chennai. The Neyveli Lignite Corporation (NLC) Ltd has the Mission "To play an active role in the society and be sensitive to emerging environmental issues". The data was collected in the Thermal power station II.

Formal consent was obtained from the subjects.The study subjects were only the temporary workers working on a contract basis at NLC Ltd. who came for duty in the day shift during the data collection and were selected as per the inclusion criteria. In this study, the independent variable was the structured-teaching programme regarding HIV/ AIDS and the dependent variables were favourable attitude towards HIV/ AIDS.

As per the inclusion criteria, male subjects aged between 20 and 50 years, as they were in the reproductive age group, who were willing to participate in the study, worked in the day shift, and were identified to possess unfavourable and neutral attitude regarding the HIV/ AIDS, were selected. Those who had already attended any structured-teaching programme or awareness programme on HIV/ AIDS, were on leave during the study period and those who were hard of hearing were excluded.

The tool consisted of an assessment of the attitude regarding HIV/ AIDS. It had 12 statements with favourable attitude and 12 statements with unfavourable attitude. 
A total of twenty-four statements were asked for assessing the attitude on HIV/ AIDS among the subjects. The scores obtained by the subjects were interpreted as follows:

- 25 - $48 \%$ : Unfavourable attitude

- $\quad 49-72 \%$ : Moderately favourable attitude

- 73 - $96 \%$ : Favourable attitude

- 97 - 120 \%: Highly favourable attitude

The developed tool was given to seven experts and content validity was obtained from them. The Cronbach alpha test was used to test the reliability and it was 0.8 .

\section{Data Collection Procedure}

Ethical clearance was obtained from the Institutional Human Ethics Committee of Annamalai University. Formal permission was obtained from the Human and Resource Director of NLC Ltd, to conduct the study in Thermal power station I and Thermal power station II. The pilot study was conducted in Thermal Power Station I and the main data collection was conducted in Thermal Power Station II from March 2012 to June 2, 2012.

After getting permission from the officials, the investigator briefed about the purpose of the study to the participants in Thermal Power Station II. The subjects were approached in groups of 15-20 during their lunch time for data collection. The questionnaire was given to the subjects. Before initiating the structured teaching programme, the contract workers were seated comfortably in the side room of the canteen and a casual conversation was started, regarding life, the importance of leading a healthy life and slowly the topic was introduced to them. The structured-teaching programme on HIV/ AIDS was given by the investigator with the use of a laptop as a power-point presentation. The subjects showed interest in knowing about the biological changes that occur after HIV infection and during disease progression. Teaching incorporated HIV testing and counselling, information such as - who has to undergo HIV testing, where the test can be done, and the discussion about the results and prevention of HIV.

After fifteen days, the investigator met the same group and a post-test I was administered. For the subjects, who had unfavourable and neutral attitude on HIV/ AIDS, a recycling decision was made and reinforcement was done with a discussion about the topic and their doubts were cleared. After one week duration, the subjects were again approached and post-test II was done to assess their attitude regarding HIV/ AIDS.

\section{Results}

The mean attitude score regarding HIV/ AIDS was found to be 69.9 with SD of 5.6 in the pre-test which increased to 103.5 with SD of 3.2 in the post-test I. With further reinforcement, the mean attitude level increased to 112.4 with the SD of 1.4. One way ANOVA repeated measures were applied to assess the changes that occurred in the mean attitude score. The results confirmed that the mean attitude score between the pre-test, post-test I, and post-test II was statistically significant at $P<0.001$ level. To find out when the changes had occurred, the repeated contrast method was applied and the results are shown in Table 1(a).

The results confirmed that there was a significant increase in the mean overall attitude score in the post-test I, when compared to the pre-test. The result was found significant at $\mathrm{P}<0.001$ level, which inferred that there was a favourable change in the attitude level in post-test II indicating that the structured-teaching programme was very effective in causing changes in the attitude of the subjects on the HIV/ AIDS. The graphical representation is shown in Figure 1.

Table I.Overall Attitude Score of the Subjects on HIV/ AIDS at Different Intervals $(\mathbf{N}=$ I 23)

\begin{tabular}{|c|c|c|c|c|}
\hline \multirow{2}{*}{ Source/ Different Intervals } & \multicolumn{2}{|c|}{ Attitude Score } & \multicolumn{2}{|c|}{ Oneway ANOVA } \\
\hline & Mean & SD & F'Value & $P^{\prime}$ Value \\
\hline Pre-test & 69.967 & 5.6582 & \multirow{3}{*}{4432.293} & \multirow{3}{*}{$\begin{array}{c}<0.001 \\
\text { S }\end{array}$} \\
\hline Post-test I & 103.553 & 3.2497 & & \\
\hline Post-test II & 112.496 & 1.4222 & & \\
\hline
\end{tabular}

««" Significant at $\mathrm{P}<0.001$ Level.

Table I(a).Comparison of the Overall Mean Attitude Score of the Subjects on HIV/ AIDS with Repeated Contrast Test $(\mathbf{N}=123)$

\begin{tabular}{|c|c|c|}
\hline \multirow{2}{*}{ Source/ Different Intervals } & \multicolumn{2}{|c|}{ Repeated Contrast Test } \\
\cline { 2 - 3 } & F' Value & P' Value \\
\hline Pre-test vs post-test I & 3665.43 & "«" $<0.001$ \\
\hline Post-test I vs post-test II & 823.947 & "«" $<0.001$ \\
\hline
\end{tabular}

\footnotetext{
«" Significant at $\mathrm{P}<0.001$ Level.
} 


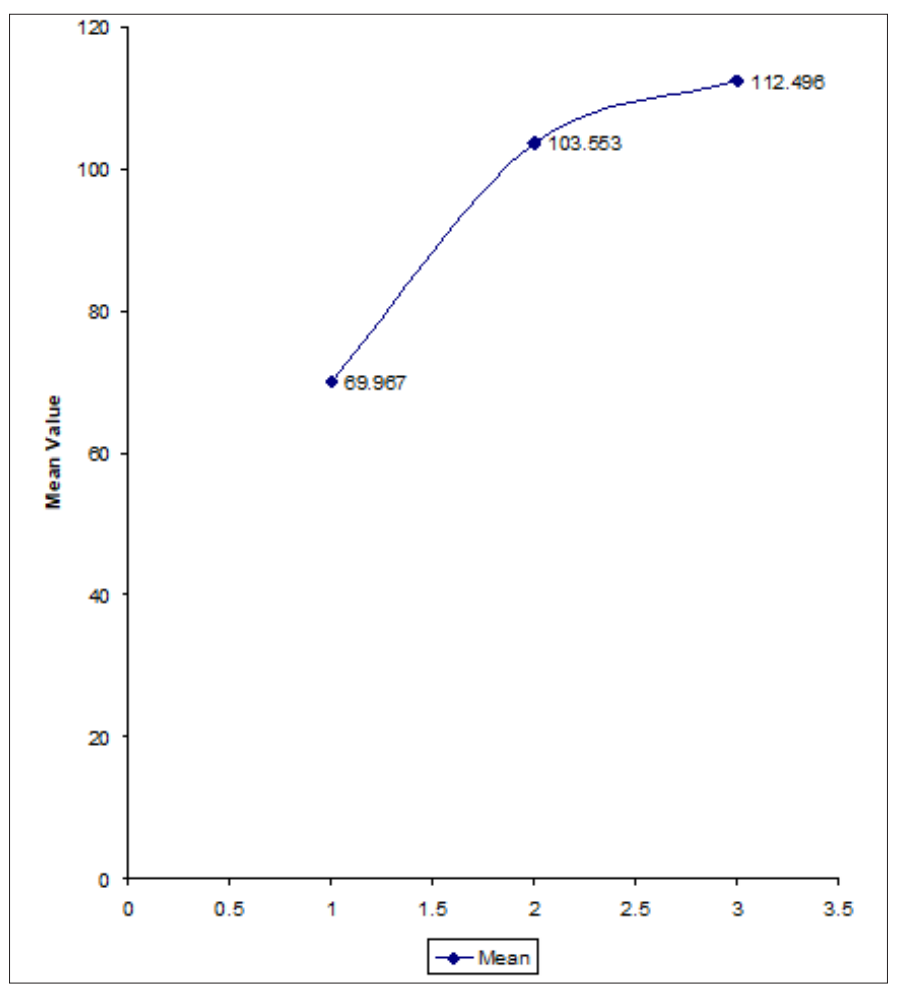

Figure I.Overall Attitude Score of the Subjects on HIV/ AIDS at Different Intervals

Table 2.Attitude Score of the Subjects on Basic Concept of HIV/ AIDS at Different Intervals $(\mathbf{N}=123)$

\begin{tabular}{|c|c|c|c|c|}
\hline \multirow{2}{*}{ Source/ Different Intervals } & \multicolumn{2}{|c|}{ Attitude Score } & \multicolumn{2}{|c|}{ Oneway ANOVA } \\
\hline & Mean & SD & F'Value & $P^{\prime}$ Value \\
\hline Pre-test & 27.797 & 3.3 & \multirow{3}{*}{1469.53} & \multirow{3}{*}{$\begin{array}{c}<0.001 \\
S\end{array}$} \\
\hline Post-test I & 39.382 & 1.8 & & \\
\hline Post-test II & 42.722 & 0.8 & & \\
\hline
\end{tabular}

«"« Significant at P $<0.001$ Level.

Table 2(a).Comparison of the Mean Attitude Score of the Subjects on Basic Concept of HIV with Repeated Contrast Test $(\mathbf{N}=$ I23)

\begin{tabular}{|c|c|c|}
\hline \multirow{2}{*}{ Source/ Different Intervals } & \multicolumn{2}{|c|}{ Repeated Contrast Test } \\
\cline { 2 - 3 } & F' Value $^{\prime}$ & ' ${ }^{\prime}$ Value \\
\hline Pre-test vs post-test I & 3665.43 & $<.001$ \\
\hline Post-test I vs post-test II & 823.947 & "'«" $<0.001$ \\
\hline
\end{tabular}

««" Significant at $\mathrm{P}<0.001$ Level.

The mean attitude score on the basic concept was found to be 27.7 with SD of 3.3 before the intervention. The mean attitude level had increased to 39.3 with SD of 1.8 in the post-test I (after 15 days of the intervention). The significant difference $(P<0.001$ level) between post-test I and post-test II inferred that there is a higher favourable attitude post-test II, when compared to post-test I indicating that the structured teaching programme was effective in changing the attitude towards the basic concept of HIV/ AIDS. Reinforcement was also useful in bringing a more favourable attitude further which is shown in Table 2(a).
In the treatment aspect also, there was a significant increase in the post-test II after the reinforcement. The results confirmed that the mean attitude score between the pretest, post-test I and post-test II was statistically significant at $\mathrm{P}<0.001$ level, which is shown in Table 3.

The mean attitude score towards HIV testing and counselling was 10.8 with SD of 2.1 in the pre-test which had increased to 17.9 with SD of 1.2. The significant $P$ value between posttest I and post-test II inferred that there was an increase in the attitude score post-test II as compared to post-test I as shown in Table 4(a). 
Table 3.Attitude Score of the Subjects on Treatment Aspect of HIV/ AIDS at Different Intervals (N = I23)

\begin{tabular}{|c|c|c|c|c|}
\hline \multirow{2}{*}{ Source/ Different Intervals } & \multicolumn{2}{|c|}{ Attitude Score } & \multicolumn{2}{c|}{ Oneway ANOVA } \\
\cline { 2 - 4 } & Mean & SD & \multirow{2}{*}{ F' Value } & P' Value \\
\hline Pre-test & 11.512 & 2.2116 & \multirow{2}{*}{1022.24} & $<0.001$ \\
Post-test I & 17.821 & 1.2938 & \\
\hline Post-test II & 19.593 & 0.5845 & & S \\
\hline
\end{tabular}

««" Significant at $\mathrm{P}<0.001$ Level.

Table 3(a). Comparison of the Mean Attitude Score of the Subjects on Treatment Aspects of HIV/ AIDS with Repeated Contrast Test $(\mathbf{N}=123)$

\begin{tabular}{|c|c|c|}
\hline \multirow{2}{*}{ Source/ Different Intervals } & \multicolumn{2}{|c|}{ Repeated Contrast Test } \\
\cline { 2 - 3 } & F' Value & P' Value \\
\hline Pre-test vs post-test I & 833.057 & "«" $<0.001$ \\
\hline Post-test I vs post-test II & 201.765 & "«" $<0.001$ \\
\hline
\end{tabular}

««" Significant at $\mathrm{P}<0.001$ Level.

Table 4. Attitude Score of the Subjects towards HIV Testing at Different Intervals $(\mathbf{N}=123)$

\begin{tabular}{|c|c|c|c|c|}
\hline \multirow{2}{*}{ Source/ Different Intervals } & \multicolumn{2}{|c|}{ Attitude Score } & \multicolumn{2}{|c|}{ Oneway ANOVA } \\
\hline & Mean & SD & F' Value & $P^{\prime}$ Value \\
\hline Pre-test & 10.87 & 2.1915 & \multirow{3}{*}{1270.188} & \multirow{3}{*}{$\begin{array}{c}\| " \ll "<0.001 \\
S\end{array}$} \\
\hline Post-test I & 17.927 & 1.2225 & & \\
\hline Post-test II & 19.634 & 0.5764 & & \\
\hline
\end{tabular}

««" Significant at $\mathrm{P}<0.001$ Level.

Table 4(a). Comparison of the Mean Attitude Score of the Subjects on HIV Testing with Repeated Contrast Test $(\mathbf{N}=$ I23)

\begin{tabular}{|c|c|c|}
\hline \multirow{2}{*}{ Source/ Different Intervals } & \multicolumn{2}{|c|}{ Repeated Contrast Test } \\
\cline { 2 - 3 } & F' Value $^{\prime}$ & P' Value \\
\hline Pre-test vs post-test I & 1155.733 & "«แ" $<0.001$ \\
\hline Post-test I vs post-test II & 192.301 & u«" $<0.001$ \\
\hline
\end{tabular}

««" Significant at $\mathrm{P}<0.001$ Level.

Table 5.Attitude Score of the Subjects on Prevention of HIV/AIDS at Different Intervals $(\mathbf{N}=123)$

\begin{tabular}{|c|c|c|c|c|}
\hline \multirow{2}{*}{ Source/ Different Intervals } & \multicolumn{2}{|c|}{ Attitude Score } & \multicolumn{2}{|c|}{ Oneway ANOVA } \\
\hline & Mean & SD & F' Value & $\mathbf{P}^{\prime}$ Value \\
\hline Pre-test & 9.033 & 1.9708 & \multirow{3}{*}{72.98} & \multirow{3}{*}{ 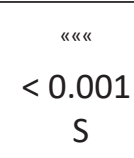 } \\
\hline Post-test I & 10.797 & 1.1232 & & \\
\hline Post-test II & 10.87 & 0.5273 & & \\
\hline
\end{tabular}

««" Significant at $\mathrm{P}<0.001$ Level.

Table 5(a). Comparison of the Mean Attitude Score of the Subjects on Prevention of HIV with Repeated Contrast Test $(\mathbf{N}=123)$

\begin{tabular}{|c|c|c|}
\hline \multirow{2}{*}{ Source/ Different Intervals } & Repeated Contrast Test \\
\cline { 2 - 3 } & F' Value $^{\prime}$ & P' Value \\
\hline Pre-test vs post-test I & 78.345 & "«" $<0.001$ \\
\hline Post-test I vs post-test II & 0.405 & $<0.5$ \\
\hline
\end{tabular}


Hence the results indicated that the intervention given had brought a change with a highly favourable attitude towards HIV testing and further reinforcement was also useful in bringing the change among the subjects.

The mean attitude score on prevention of HIV was 9.0 with SD of 1.9 in the pre-test which had a mean score of 10.7 and SD of 1 . The mean attitude score increased to 10.8 with SD of 0.5 in the post-test II as shown in Table 5. To find whether the mean scores were statistically different, one way ANOVA repeated measures was applied. The significant ' $P$ ' value confirmed that the mean values at pre-test, post-test I and post-test II were statistically different. To find out when the changes had occurred, the repeated contrast method was applied and the results are shown in Table 5(a).

The repeated contrast test results indicated that there is a significant change in the attitude level post-test I as compared with the pre-test, where the ' $P$ ' value is $<0.001$. The ' $P$ ' value between post-test I and II inferred that there is only a slight change in the attitude level regarding prevention. The result indicated that the structured-teaching programme had only a little impact on changing the attitude towards prevention of HIV among the subjects as shown in Figure 2.

The mean attitude score regarding the belief regarding the rights of HIV/ AIDS affected people was 10.7 with SD of 2.1, and increased to 17.6 with SD of 1.4 in post-test I (after the intervention). With further reinforcement, the mean attitude score further increased to 19.6 with SD of 0.5 which means the subjects had developed a highly favourable attitude towards the rights of the HIV affected people. The significant ' $P$ ' value between post-test I and post-test II inferred that there is a higher favourable attitude towards the rights of the HIV affected people at post-test II as compared to posttest I as shown in Tables 6 and 6(a).

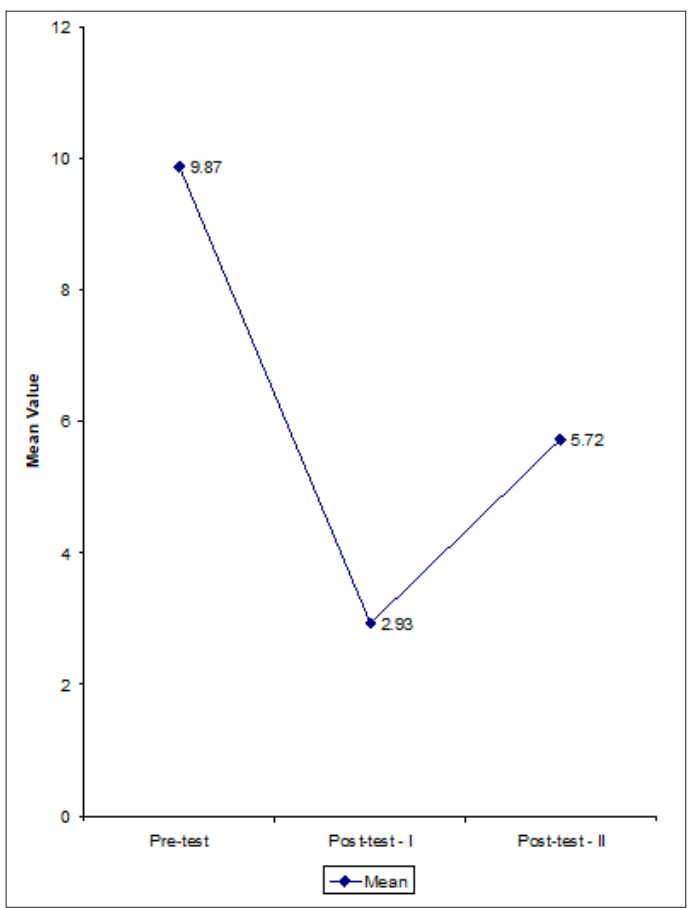

Figure 2.Attitude Score of the Subjects on Prevention of HIV/AIDS at Different Intervals

\section{Discussion}

The aim of the study was to explore the attitude regarding HIV/ AIDS among industrial workers, working in the public sector. The WHO's focus for the 2014 campaign was closing the gap in HIV prevention and treatment. According to the International Labor Organization (ILO), 26 million people are industrial workers. Preventing the spread of HIV begins with education. Educating the public through awareness campaigns coupled with one to one knowledge sharing has proven to be effective. Education efforts also focus on

Table 6.Attitude Score of the Subjects on the Rights of the HIV affected People at Different Intervals $(\mathbf{N}=$ I23)

\begin{tabular}{|c|c|c|c|c|}
\hline \multirow{2}{*}{ Source/ Different Intervals } & \multicolumn{2}{|c|}{ Attitude Score } & \multicolumn{2}{|c|}{ Oneway ANOVA } \\
\hline & Mean & SD & $F^{\prime}$ Value & P' Value \\
\hline Pre-test & 10.756 & 2.16 & \multirow{3}{*}{1230.46} & \multirow{3}{*}{$\begin{array}{c}<0.001 \\
S\end{array}$} \\
\hline Post-test I & 17.626 & 1.45 & & \\
\hline Post-test II & 19.626 & 0.54 & & \\
\hline
\end{tabular}

"«"Significant at $\mathrm{P}<0.001$ Level.

Table 6(a).Comparison of the Mean Attitude Score of the Subjects on Beliefs of the Rights of the HIV affected People with Repeated Contrast Test $(N=123)$

\begin{tabular}{|c|c|c|}
\hline \multirow{2}{*}{ Source/ Different Intervals } & \multicolumn{2}{|c|}{ Repeated Contrast Test } \\
\cline { 2 - 3 } & $F^{\prime}$ Value & P' Value \\
\hline Pre-test vs post-test I & 1047.789 & ««" $<0.001$ \\
\hline Post-test vs post-test II & 194.883 & «"«" $<0.001$ \\
\hline
\end{tabular}

"«" Significant at $\mathrm{P}<0.001$ Level. 
encouraging behaviour change, such as reduction in the number of sexual partners, increased use of condoms, and delaying the start of sexual activity. ${ }^{7}$

The findings of the present investigation with respect to the attitude on HIV testing were that 161 (64.4\%) had a neutral attitude to undertake the HIV testing. Tran B X, et al. in their cross-sectional study, assessed the VCT uptake and HIV related knowledge, attitude and perceived risks, and identified that majority of the subjects were less likely to have a voluntary test. ${ }^{8}$

The results were congruent with a cross-sectional survey done by Thu M, Kyu H H and Putten M V among the Myanmar migrant workers in which more than half of the respondents had misconceptions on prevention of HIV/ AIDS and there was no significant association of knowledge and condom use but a positive attitude was associated with safe practice. ${ }^{9}$ The researchers suggested that more efforts were to be made to provide information, education, and communication to the Myanmar migrants to promote their knowledge level and to alter misconception.

In the present study with respect to the attitude towards marrying an HIV positive person, working with an HIV positive person, a total of 155 (62.1\%) subjects had a neutral attitude and 38 (15.2\%) subjects had a favourable attitude on the rights of the HIV affected people. Zahidul Islam Biswas explored and identified that a good number of countries have already enacted laws giving legal right to marry an AIDS patient, but it is still undecided in most of the countries of the Globe. ${ }^{10}$ India and Bangladesh are two neighbouring countries that do not have specific legislation settling the issue, though HIV/ AIDS is considered to be an agreed threat to both Indian and Bangladeshi society.

A more favourable result and positive attitude were identified in the study of Bounbouly, et al. where the attitude on studying in a school with HIV positive friends was favourable with $45.3 \%$ of the subjects and $124(41.3 \%)$ said that they would continue in the school with HIV positive teachers. ${ }^{11}$ The authors suggested and recommended that education programmes with specific interventions would increase the KAP to prevent HIV infections.

Bateesa SC explored the workers' rights and their attitude on workplace response to HIV/ AIDS. ${ }^{12}$ Their study revealed that the working population were ignorant about the workplace HIV/ AIDS and their relevance to workers living with HIV/ AIDS and identified that a significant proportion of the respondents had lost jobs due to their HIV status and it had also affected the occupation, career, and income.

\section{Conclusion}

The one way ANOVA results showed a significant ' $P$ ' value of $<0.001$ which indicated that the structured-teaching programme was effective in improving the overall attitude on HIV/ AIDS of the subjects. With the repeated contrast test, results showed a significant ' $P$ ' value of $<0.001$ which indicated that the structured-teaching programme was effective in improving the overall attitude, basic concepts, HIV testing, treatment aspects on the HIV/ AIDS of the subjects at different intervals were found to be favourable.

The mean attitude scores of the subjects regarding the rights of the HIV affected people were highly favourable, whereas in the prevention aspect there was only a slight change in the attitude.

\section{Hypothesis}

The hypothesis that there will be a significant change in the subjects' attitude after the STP on HIV/ AIDS was accepted at $<0.001$ level.

\section{Recommendations}

The nursing personnel can allot nursing staff and students for guiding the public to undergo HIV testing and can emphasise the importance of it. Ethnographic research can be conducted in the risky population. The issues about the rights of HIV affected people could be addressed.

\section{Acknowledgement}

The researchers would like to acknowledge the study subjects for their involvement and participation in the conduction of this research, and the Institutional Human Ethics Committee for the permission to conduct the research.

The researchers also thank their friend for reviewing this article and for the suggestions.

\section{Abbreviations}

AIDS: Acquired Immunodeficiency Syndrome

ANOVA: Analysis of variance

ART: Antiretroviral Treatment

HAART: Highly Active Antiretroviral Therapy

HCT: HIV counselling and testing

HIV: Human Immunodeficiency Virus

STP: Structured Teaching Programme

WHO: World Health Organization

\section{Sources of Funding: None \\ Conflict of Interest: None}

\section{References}

1. Kawale SK, Sharma V, Thaware PP, Mohankar AD. Knowledge, attitude and perception regarding HIV/ AIDS among postgraduate students of university of Pune. Family Med Prim Care. 2020;9(3):1728-32.

2. Bowen P, Allen Y, Edwards P, Cattell K, Simbayi L. Guidelines for effective workplace HIV/AIDS intervention management by construction firms. Constr Mgmt Eco. 2014;32(4):362-81. [Google Scholar]

3. Maheswari S, Muthamilselvi G. Assess the Effectiveness 
of structured Teaching programme on Universal Precaution among class IV employees working at Aarupadai Veedu Medical College and Hospital, Puducherry, India. Am J Nurs Res. 2014;2(2):26-30. [Google Scholar]

4. Mathew RS, Reshma V, Sabith M, Rajan SM, Sam $\mathrm{S}$, Roshith KP. Structured Teaching Programme on HIV/AIDS: An evaluatory approach. Int J Rec Sci Res. 2013;4(9):1427-31.

5. Ouzouni C, Nakakis K. HIV/AIDS knowledge, attitudes and behaviours of student nurses. Health Sci J. 2012;6(1):129-60. [Google Scholar]

6. Tessema B, Biadglegne F, Mulu A, Getachew A, Emmrich F, Sack U. Magnitude and determinants of nonadherence and nonreadiness to highly active antiretroviral therapy among people living with HIV/ AIDS in Northwest Ethiopia: a cross sectional study. AIDS Res Ther. 2010;7:2. [PubMed] [Google Scholar]

7. The Global Fund to fight AIDS-2015 [Internet]. Available from: https://www.theglobalfund.org

8. Tran BX, Nguyen LT, Nguyen NP, Phan HTT. HIV voluntary testing and perceived risk among female sex workers in the Mekong Delta Region of Vietnam. Glob Health Act. 2013;6(1). [Google Scholar]

9. Thu M, Kyu HH, Putten MV. Knowledge, attitude and practices on HIV/AIDS prevention among Myanmar migrants in Maha Chai, Samut Sakhon Province, Thailand. 2007. [Google Scholar]

10. Biswas ZI. HIV patients' Right to Marry: IndianBangladeshi laws in Perspective. Law and our Rights: The Daily Star. 2008;55. [Google Scholar]

11. Thanavanh B, Harun-Or-Rashid M, Kasuya H, Sakamoto J. Knowledge, attitudes and practices regarding HIV/ AIDS among male high school students in Lao People's Democratic Republic. J Int AIDS Soc. 2013;16(1):17387. [PubMed] [Google Scholar]

12. Bateesa SC. Workplace response to HIV/AIDS and the effect of HIV/AIDS on the carriers and occupations of the infected urban population [thesis]. M Phil Industrial Psychology HIV/AIDS management, University of Stellenbosch; 2009. [Google Scholar] 


\section{Tool used for Assessing the Attitude about HIV/ AIDS}

\begin{tabular}{|c|c|c|c|c|c|c|}
\hline \multicolumn{7}{|c|}{ Attitude and beliefs regarding HIV/ AIDS } \\
\hline \multicolumn{7}{|c|}{$\begin{array}{l}\text { Kindly read the following statements and give your response for each of the statement as per your opinion. } \\
\text { Kindly put a tick mark }(\mathrm{V}) \text { in the appropriate column against each statement. The information given by you will be } \\
\text { kept confidential. }\end{array}$} \\
\hline $\begin{array}{l}\text { S. } \\
\text { No. }\end{array}$ & Content & \begin{tabular}{|c|}
$\begin{array}{c}\text { Strongly } \\
\text { agree }\end{array}$ \\
\end{tabular} & Agree & Uncertain & $\begin{array}{l}\text { Strongly } \\
\text { Disagree }\end{array}$ & Disagree \\
\hline \multicolumn{7}{|c|}{ Beliefs related to Basic Concept and Spread of HIV/ AIDS } \\
\hline$* 1$ & $\begin{array}{l}\text { HIV/ AIDS is a punishment } \\
\text { for immoral behaviour. }\end{array}$ & & & & & \\
\hline 2. & $\begin{array}{l}\text { I think women should not have sexual intercourse } \\
\text { before marriage. }\end{array}$ & & & & & \\
\hline *3. & $\begin{array}{l}\text { If I stand near an HIV person who coughs or sneezes } \\
\text { I will get the HIV infection. }\end{array}$ & & & & & \\
\hline$* 4$ & $\begin{array}{l}\text { I believe that there are chances of contracting HIV } \\
\text { working near someone who is HIV positive. }\end{array}$ & & & & & \\
\hline 5. & $\begin{array}{l}\text { I believe shaking hands, touching or kissing on the } \\
\text { cheek with someone who has HIV will not spread } \\
\text { the infection. }\end{array}$ & & & & & \\
\hline 6. & $\begin{array}{l}\text { I believe using public toilets and public telephone } \\
\text { will not cause HIV infection. }\end{array}$ & & & & & \\
\hline$* 7$ & $\begin{array}{l}\text { I believe eating in a restaurant where the cook has } \\
\text { HIV will cause the HIV infection. }\end{array}$ & & & & & \\
\hline 8. & $\begin{array}{l}\text { I believe I could comfortably discuss about HIV/ AIDS } \\
\text { with a friend. }\end{array}$ & & & & & \\
\hline$* 9$ & $\begin{array}{l}\text { I think I could tell by looking at someone if he/ she } \\
\text { had HIV/ AIDS. }\end{array}$ & & & & & \\
\hline \multicolumn{7}{|c|}{ Beliefs related to Treatment of HIV/ AIDS } \\
\hline 10. & $\begin{array}{l}\text { I think that my health will be good if I continue the } \\
\text { drugs for HIV. }\end{array}$ & & & & & \\
\hline 11. & $\begin{array}{l}\text { I think taking nutritious diet is good with the ART } \\
\text { drugs. }\end{array}$ & & & & & \\
\hline$* 12$. & $\begin{array}{l}\text { I think I will feel irritated to check the CD4 counts } \\
\text { often. }\end{array}$ & & & & & \\
\hline 13. & $\begin{array}{l}\text { I believe it is necessary to continue the ART } \\
\text { medications even when there are side effects. }\end{array}$ & & & & & \\
\hline \multicolumn{7}{|c|}{ Beliefs related to HIV Testing and Counselling } \\
\hline$* 14$. & $\begin{array}{c}\text { I think that explanation and consent is unnecessary } \\
\text { before being tested for it. }\end{array}$ & & & & & \\
\hline 15. & $\begin{array}{l}\text { I feel that I will become anxious to undergo the HIV } \\
\text { testing. }\end{array}$ & & & & & \\
\hline 16. & $\begin{array}{l}\text { I believe that the children born to HIV infected or } \\
\text { high-risk parents should undergo HIV testing. }\end{array}$ & & & & & \\
\hline$* 17$. & $\begin{array}{l}\text { I feel that the results can be informed to the person } \\
\text { directly. }\end{array}$ & & & & & \\
\hline
\end{tabular}


Beliefs related to Condom Use in Prevention of HIV/ AIDS

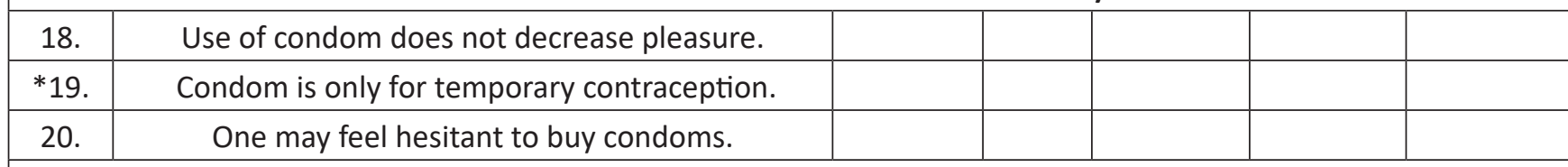

Beliefs and Attitude related to the Rights of HIV/ AIDS Patient

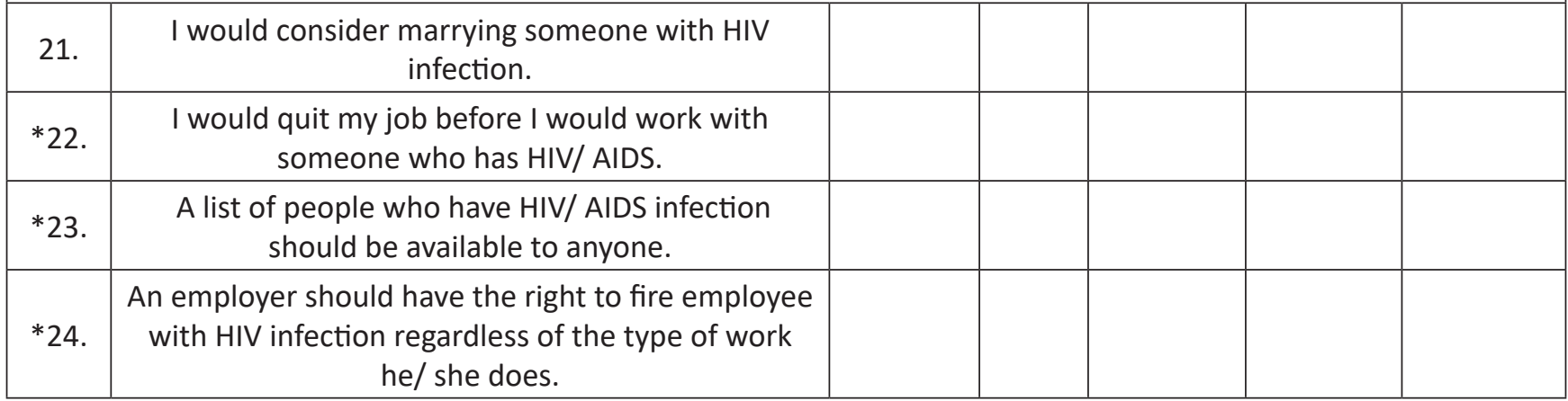

